\title{
Nuclear and Cell Division in Dictyota dichotoma.
}

\author{
BY
}

\author{
DAVID M. MOTTIER, \\ Professor of Botany in the Indiana University. \\ With Plate XI. \\ $\rightarrow-$
}

\begin{abstract}
$\triangle$ MONG the Brown Algae certain representatives, as A Fucus, Stypocaulon, Sphaceleria, and Dictyota, have, in recent years, been found to afford favourable material for the investigations of cytologists dealing with nuclear and cell-division. One of these genera, Stypocaulon (Swingle, '97), was the first Alga in which the persistence of the centrosome was, without doubt, demonstrated throughout successive generations of vegetative cells. The discovery, in 1897, of motile antherozoids in Dictyota and Taonia by Williams ('97) has aroused a renewed interest in the Dictyotaceae from the standpoint of evolution, and my own observations will show, I think, that in the tetraspore mother-cells of this plant we have a rather favourable object for a study of the centrosphere and the development of the karyokinetic spindle, as well as the formation of the cell-plate.

A short sojourn at the Zoological Station in Naples, in the spring of 1898 , enabled me to collect material and to make a preliminary study of the centrosphere, the results of which have already been published in the Berichte der

[Annals of Botany, Vol. XIV. No. LIV. June, I900.]


Deutschen Botanischen Gesellschaft. Since that time I have been able to make a somewhat exhaustive study of the entire process of nuclear and cell-division in both vegetative cells and tetraspore mother-cells, and the results of this study are set forth in the following pages.

\section{METHOD.}

To the cytologist the method by which results are obtained is always of prime importance, since the improvement of older methods or the discovery of new ones is one of the principal channels through which progress in cytology is possible; and as certain features in the method used proved somewhat surprising, a brief statement of the same may be useful to others pursuing similar lines of investigation.

In the beginning of my study the same combination of chromic-osmic-acetic acid, which gave such remarkably good results for the pollen mother-cells in Lilium and other higher plants, was used, except that the solution of chromic acid was made from sea water, namely: Solution A,

1 or $\frac{1}{2} \%$ chromic acid (in sea water) $16 \mathrm{cc}$.

$2 \%$ osmic acid . . $3 \mathrm{cc}$.

Glacial acetic acid . . . I cc.

If the objects were left in the fluid for a longer time, one-half per cent. chromic acid was used instead of one per cent.

Material fixed in this fluid, when worked up immediately, proved to be so blackened, that preparations, even of very thin sections, were unsatisfactory and generally worthless. Much time and patience were required to determine the amount of osmic acid necessary to fix cytoplasmic structures well, with as little blackening as possible. At first the above solution $\mathrm{A}$ was diluted with an equal volume of sea water, which I shall designate solution B. When the solution was diluted one-half, one per cent. chromic acid was always used in the original. This also proved to blacken too much. Several solutions were then tried, in which one to four drops 
(I drop being about one-twentieth of a cc.) of the two per cent. osmic acid were added to ten cubic centimetres of chromic acid and about one-half cubic centimetre of glacial acetic acid. One drop of the two per cent. osmic acid proved sufficient in some cases to give good results. The formula would then be as follows :-

$1 \%$ chromic acid (in sea water) . IOcc.

$2 \%$ osmic acid I to 3 drops (I drop $=.05 \mathrm{cc}$.)

Glacial acetic acid . . . $.5 \mathrm{cc}$.

It was upon material fixed in this last-named solution that the results of my preliminary paper were obtained.

Pieces of the plant, on being thrown into these fluids, became dark almost at once, but after a short time the dark colour of the thallus disappeared owing to the oxidation caused by the chromic acid.

Since it was impossible to make in any way an exhaustive study during my stay at the Station in Naples, material fixed in the above solutions, and also in various strengths of Vom Rath's platinum-chloride-osmic-acetic acid, was brought gradually into seventy per cent. alcohol, where it lay until ready for use, which was during the following December and January, I 899 .

In the course of investigation, material which had been fixed in the solutions A and B previously mentioned, gave, to my agreeable surprise, excellent results, for many preparations made from such material left little to be desired. Vom Rath's fluid gave less satisfactory results.

In thin sections the blackening was readily removed by allowing the slide to remain for a short time in a bath of alcohol and hydrogen peroxide $(70 \mathrm{cc}$. of $80 \%$ alcohol and $30 \mathrm{cc}$. of hydrogen peroxide).

Material fixed in solutions weak in osmic acid gave good results also after lying in the seventy per cent. alcohol for the time mentioned, but differential staining was more difficult and less satisfactory. The radiations and spindle-fibres retain the stain with less avidity, consequently the finer 
details of both nuclear figure and remaining cytoplasm are less sharply defined. The staining process was the same as that used by myself in cytological studies on the higher plants (Mottier, '97, '98).

\section{The Cytoplasm.}

The following remarks pertain to the tetraspore mother-cell, unless otherwise stated.

The cytoplasm, especially during the preparation for the process of nuclear division, reveals two well-defined and sharply differentiated portions, a fibrillar portion, the kinoplasm, which is always associated with the nucleus and which plays the most important rôle in the karyokinetic process, and the remaining alveolar portion or trophoplasm of Strasburger. The alveoli (Waben of German authors) are relatively large and generally uniform in size (Plate XI, Figs. 2, 8); their walls or lamellae are generally smooth and of a uniform thickness. Upon the lamellae and in the angles of their meshes are often present numerous small granules which impart the granular appearance to the alveolar structure. Among the larger alveoli there are also present, especially in the vicinity of the nucleus, smaller meshes of granular plasma. This is partly fibrillar and partly alveolar.

In neither the reproductive nor the vegetative cells of Dictyota do we have a differentiation of the alveolar plasm into two sharply defined zones as in Stypocaulon (Swingle, '97, Figs. I and 4), namely a region of rather uniform and small meshes surrounding the nucleus and one of much larger meshes occupying the remaining part of the cell.

Regarding the terms kinoplasm and trophoplasm, Strasburger ('98), in a critical and exhaustive discussion of the cell-wall and its origin, proposes for these physiological terms others of morphological significance, namely, filar plasma and alveolar plasma. He does not intend, it seems, that the latter terms should entirely replace the former, but that they. be used in connexion with them (p. $5^{17}$ ). 
'Da die von mir vorgeschlagenen Bezeichnungen inzwischen eine ziemliche Verbreitung fanden, so möchte ich sie nicht ganz fallen lassen. Auch scheinen sie mir bei unserer jetzigen Kenntniss vom Zellenleben immerhin noch brauchbar zu sein; andererseits kann ich jetzt auch morphologische Bezeichnungen vorschlagen, die sich vielleicht neben den physiologischen zum Gebrauch empfehlen würden.'

It may be reasonably questioned whether the morphological terms are more fitting than the physiological, for, as it will be shown in what follows, the kinoplasm may not necessarily exist in the form of fibrillae, or that condition in which it is found when in the active state during karyokinesis. In the opinion of the writer the term kinoplasm is an especially fortunate one, since it cannot be doubted for an instant that, during nuclear division, there exists in the cytoplasm a differentiation which is the expression of a division of labour, and that the kinoplasm is more directly concerned in the mechanics of nuclear division than the remaining cytoplasm. It is not necessary to assume that kinoplasm is a morphological constituent of the cytoplasm, yet there is much to support this view, as the investigations of Strasburger previously cited, and my own studies on pollen and embryosac mother-cells amply show. Even were there no such evidence, the term would be justified merely as one of description to designate that part of the cytoplasm which is instrumental in the formation of the nuclear spindle.

The term trophoplasm is probably less fortunate and may lead to misunderstanding. The term kinoplasm I shall use in the following pages in its original sense ; the word trophoplasm will not be used at all. It is not necessary to assume that all the protoplasm of a cell is either alveolar or fibrillar to explain the phenomena presented in a well-fixed and stained cell. As plant-cells plainly show, both forms may be present in the same cell, the net-like threadwork merging almost imperceptibly into the alveolar structure, as is undoubtedly the case in Dictyota.

In the tetraspore mother-cells the chloroplasts are numerous, 
though smaller than in the ordinary epidermal or superficial cells of the thallus. This is because of their rapid multiplication during the growth of the tetraspore mother-cells. In the medullary or central cells of the thallus only a few smaller chloroplasts are present. They may be elongated, elliptical, bean-shaped, or often globular. They do not as a rule lie in the cavities of the alveoli, but are applied to their walls or to the threads of the cytoplasmic framework. Even after the process of fixing, imbedding, and staining, they still retain their brown colour, which, however, is paler than in the living cell.

\section{THE NuCLEus.}

As in Stypocaulon, there is only one nucleus in each cell. In one case an apical cell was observed in which two nuclei in the resting condition lay very close together. In this instance nuclear division had been completed before a cellplate had put in an appearance. Whether this is purely an exceptional case, or whether in the apical cell, cell-division is later in point of time than in other vegetative cells could not be decided. It is highly probable that this is exceptional, for in other vegetative cells cell-division was well under way before the daughter nuclei had passed into the complete resting stage. When the tetraspore mother-cell has increased considerably in size, the nucleus also becomes proportionately enlarged. Indeed, as pointed out by Swingle ('97) for Stypocaulon, the size of the nucleus seems to be in some degree proportional to the size of the cell. The nucleus contains one very large nucleolus, invariably much vacuolated, and a fine linin-reticulum, upon which are distributed fine granules varying somewhat in size. Many of these granules, but not all, constitute the chromatin. With the exception of the larger ones, which are more densely stained, they present the same greyish colour as the linin.

The amount of chromatin in the primary nucleus of the tetraspore mother-cell is certainly less in proportion to the size of the nucleus than in the vegetative cells. In fact 
there is much to indicate that this amount is nearly the same in all nuclei, those of vegetative cells appearing on account of their smaller size richer in this substance. In the primary nucleus, during the prophase, there is never developed the rather regular and uniform chromatin-spirem, such as is present in the vegetative cells (compare Figs. 2 and I 8 ), but instead the chromatin is collected into masses more or less isolated from which are eventually formed the chromosomes (Fig. 2). In the vegetative cells, on the other hand, there is developed a chromatin-spirem, as in the higher plants (Fig. I 8).

\section{Karyokinesis in the Tetraspore Mother-Cells.}

The development of the karyokinetic spindle in the Phaeophyceae has been studied recently by Strasburger ('97), and by Farmer and Williams ('98) in Fucus, and by Swingle ('97) in Stypocaulon.

In the vegetative cells of Stypocaulon, according to Swingle (l. c., p. 3I5), the first indication of karyokinesis is the division of a small deeply stained granule or granules, adhering closely to the nuclear membrane, from which kinoplasmic fibres radiate. This granule or pair of granules is probably homologous with the centrosome or microcentrum of Heidenhain, and possibly with the centriole of Boveri, and for the sake of convenience each body or pair of granules is spoken of as a centrosome. The division of the cluster of kinoplasmic radiations takes place simultaneously with the separation of the daughter centrosomes (1. c., Figs. 9 and 2, Taf. XV ; Figs. I3 and 14, Taf. XVI). This all happens before the cellplate which follows the division of the nucleus is formed. After the formation of the cell-plate the daughter centrosomes have assumed their definite positions. The angular distance on the surface of the nucleus traversed by the separating daughter centrosomes varies from $180^{\circ}$ to $\mathrm{I} 35^{\circ}$ in the different successive segments. While this is taking place, the chromatin framework and the nucleolus undergo certain changes 
which need not be mentioned here. During these processes also the dark bodies at the poles, which were previously dumb-bell shaped, have become thin and sharply bent at the middle (1. c., Fig. 7, upper pole, and Fig. Io, Taf. XV). They are concealed by the densly crowded kinoplasmic fibres which penetrate the membrane and enter the cavity of the nucleus.

These filaments, spreading out laterally, grow towards the centre of the nuclear cavity (1. c., Fig. I7, Taf. XVI). At about this stage the very small, deeply staining chromosomes begin to collect at the ends of the entering fibres (1. c., Fig. I8, Taf. XVI). Even before the chromosomes collect at the ends of the spindle-fibres, it may be seen that they end in a blunt point, or in a little granule or knob whose diameter is, however, only slightly larger than the fibre. As the spindle-fibres penetrate further inward, the chromosomes are heaped up in an irregular mass near the centre of the nuclear cavity (1. c., Fig. 20, Taf. XVI). The polar radiations are less pronounced and the nucleolus has entirely disappeared. The next stage is that of the equatorial plate, where the chromosomes are arranged in a plane, others forming the base of two pyramids of spindle-fibres (1. c., Fig. 2I, Taf. XVI).

Strasburger's account of the formation of the spindle in Fucus is much less complete as to details, but there is no doubt that it is similar to that of Stypocaulon.

In describing the process in Dictyota I shall begin with the first nuclear division in the tetraspore mother-cell at the time when the two centrospheres are on exactly opposite sides of the nucleus.

As soon as the tetraspore mother-cell has increased sufficiently in size to be hemispherical in shape or even a little larger, and to appear very conspicuous beside the neighbouring superficial cells, as I have described in my preliminary note (Mottier, '98), there appear on opposite sides of the nucleus two large, sharply-defined clusters or asters of kinoplasmic fibres radiating from a rod-shaped body often slightly bent, 
lying either closely applied to the nuclear membrane or at some little distance from it (Plate XI, Fig. I). This rodshaped body is the centrosome, which, together with its kinoplasmic radiations, I shall speak of as the centrosphere. The planes of the longitudinal axes of the centrosomes may be parallel or form various angles with each other. In Fig. I the centrosome at the upper side of the nucleus is seen from the side, the lower from the end. Viewed from the pole the centrosonie is always rod-shaped. The kinoplasmic fibres radiate in all directions into the cytoplasm, where they pass over into the framework of the same (Fig. 2). On the side next the nucleus they may run parallel with its wall for some distance. Near the nucleus the cytoplasm is more granular, with smaller meshes. It is more nearly a threadlike network than alveolar in structure, and appears with differential staining as kinoplasm. This very fine granular threadwork often extends in among the radiations of the centrosphere. The chloroplasts may extend close up to the nucleus (Fig. 3) or remain some distance from it (Fig. 2).

As karyokinesis progresses, the centrospheres become more conspicuous, the number of kinoplasmic radiations undoubtedly increasing.

While this is going on certain changes have taken place in the nucleus. At first there is present a large vacuolated nucleolus and a fine linin-reticulum with rather large meshes, upon which are arranged small and nearly uniform granules, all of which, as previously mentioned, are not chromatin. The chromatin now begins to collect into larger and somewhat irregular masses that finally become the chromosomes. The nucleolus becomes more vacuolated and soon disappears. The nuclear cavity presents a more granular appearance, the granules staining more densely.

The kinoplasmic fibres now penetrate the membrane of the nucleus and enter its cavity, while at the same time the polar radiations diminish in number (Figs. 2 and 3). They do not enter the cavity so uniformly as in Stypocaulon, but some proceed much in advance of others. These fibres are 
not truncated at the ends, but somewhat attenuated or rather of a uniform diameter throughout. On entering, some pass straight toward the centre of the nucleus, while others diverge toward the sides. As these fibres approach from opposite sides of the nucleus, they tend to collect the chromosomes into an irregular mass in the equatorial region, where they finally form the nuclear plate (Figs. 4, 5, 6). Certain of the fibres coming from opposite sides seem to unite at their ends to form the continuous spindle-fibres which extend from pole to pole; others fasten themselves to the chromosomes, and still others diverge toward the nuclear wall in the equatorial region. In the mature spindle, therefore, the fibres present the following orientation: those radiating from the poles, the continuous spindle-fibres extending uninterruptedly from pole to pole, those running from the poles to the chromosomes, and the fibres which diverge from the poles toward the equatorial region and end in the cytoplasm. Of the latter there are fewer in the mature spindle than at an earlier stage. In addition to the phenomena just described, several others may now be mentioned. Sometimes (Fig. 3) the nuclear membrane is apparently pushed in at the poles where the spindle-fibres penetrate. This may be due in part to a slight shrinkage. Up to this stage the nuclear membrane is unbroken. As the spindle-fibres enter the nucleus, its membrane begins to disappear at the poles, and very soon it is no longer to be recognized as such at those points, while at the sides it remains almost unchanged until a later stage or after the spindle is fully formed (Figs. 4, 5, 6), when all traces of nuclear membrane finally disappear. Thus the spindle, with the exception of the polar radiations, lies within the nuclear cavity, its fibres, however, being of cytoplasmic origin. How far any nuclear substance contributes to the formation of the spindle is difficult to decide.

As previously mentioned, the polar radiations become much less pronounced and apparently fewer in number as soon as the spindle-fibres enter the nucleus. The centrosomes also become smaller (Fig. 5), being frequently almost concealed 
by the closely arranged kinoplasmic radiations, and the nucleolus rapidly disappears.

On the disappearance of the nucleolus numerous granules appear in the nucleus, which stain deeply, closely resembling the chromatin granules. In the mean time the chromosomes increase in size, and it seems reasonable to suppose that the nucleolar substance contributes materially to their growth. The behaviour of the nucleolus during the second mitosis, as will be shown later, seems to strengthen this view.

The chromosomes when arranged in the equatorial plate appear, especially when crowded together, which is often the case, as rounded lumps. A careful study in favourable cases shows clearly that each chromosome is either in the shape of a ring, so contracted as to leave scarcely any central space, such, for example, as is known to exist in higher plants (Podophyllum and Helleborus), when each segment or daughter chromosome forms one-half of the ring, or it may be in the form of a short thick $U$ (Figs. 5 and 6). Sixteen chromosomes, the reduced number, are present in the first mitosis. To this part of the problem I shall return in a later paragraph.

While on the way to the poles the daughter chromosomes sometimes fuse with one another to form large masses; this is especially so in the second mitosis. In the construction of the daughter nuclei one or more larger masses of chromatin are formed by the chromosomes, a nucleolus appears near the chromatin mass or masses, and a nuclear membrane is laid down (Fig. 8). The membrane is unquestionably formed through the agency of the kinoplasmic fibres. The centrosome increases in size and the polar radiations are more distinct than in the spindle stage. The connecting fibres usually persist until the nuclear membrane is present, but a little later they disappear entirely. The chromatin mass gradually becoming less dense, soon disintegrates and the daughter nucleus passes into the resting condition (Figs. 9, Io).

During the reconstruction of the daughter nucleus the centrosome divides longitudinally, as it seems, the daughter 
segments separating first at one end, so that a V-shaped figure immediately results (Fig. 9). The radiations are also divided, as a cluster is attached to each daughter centrosome. It is inferred that the centrosome splits longitudinally in division, from the manner in which the kinoplasmic radiations are attached to the daughter centrosomes, and from the fact that these bodies are always rod-shaped and nearly of the same length.

The daughter centrosomes now separate, moving along the nuclear membrane, but do not, as in the first mitosis, traverse an angular distance of $180^{\circ}$ before the formation of the spindle begins (Figs. IO, I2, I3). From each centrosome a diverging bundle of fibres enters the nucleus, which contains a very fine network of linin with small scattered chromatin masses and a large nucleolus (Fig. II). In this figure only one pole of the spindle-rudiment is shown, the other being in another section. At a little later stage these fibres form cone-shaped collections with their bases directed toward the chromatin, and a deeply staining mass, which is probably the disorganizing nucleolus (Fig. 12). This stage of the karyokinetic figure bears a striking resemblance to that observed by Harper ('97) in certain Ascomycetes. As the spindle-fibres within the nucleus increase in number, the polar radiations diminish, so that often only very feeble asters remain (Figs. 12, I3). The bases of the two cones of fibres unite to form a curved spindle, while at the same time the chromatin is arranged in the equatorial region; the nucleolar mass gradually becomes less and finally disappears (Fig. I3). The granular network still persists until a later stage, and seems to take no part in the formation of the spindle, or, at most, plays only a secondary rôle. The nuclear membrane disappears soon after the spindle is mature, generally before metakinesis, but the outline of the nuclear cavity now occupied by the karyokinetic figure may be distinguished at a later stage. The spindle of the second mitosis is smaller than that of the first, and may remain slightly curved until metakinesis. The orientation of its fibres is the same, and the 
centrosomes undergo a similar diminution in size. The invariable tendency of the chromosomes to collect and fuse into larger masses has made it impossible to determine accurately their number in this division. In the equatorial plate often only two large chromatin masses are seen (Figs. I4 and $I_{5}$ ), but from the number that can be clearly made out in the first division one cannot assume that these two masses represent only two chromosomes.

The condition of the daughter nuclei presents nothing different from what has already been described for the preceding mitosis. The connecting fibres likewise disappear entirely.

\section{Karyokinesis in Vegetative Cells.}

In vegetative cells it is far more difficult and time-consuming to obtain as complete a series of stages in the development of the spindle as I was able to observe in the tetraspore mother-cells, but a sufficient number was found to indicate without much doubt what the process is, and to furnish data for a comparison with what has just been described.

The resting nucleus presents nothing out of the ordinary. Neither in the apical cell nor in any other was I able to demonstrate an aster or centrosphere at all times during the so-called resting period, but as soon as karyokinetic activity begins, an aster is always to be observed near the nucleus, even while the latter still presents the structure characteristic of the complete resting stage (Fig. I 7 ). I have, however, observed the centrosomes with few but distinct radiations in the stalk-cell of a tetrasporangium, and often in other cells, which had been in the resting stage for a relatively long time, and which would probably not undergo further division.

From the very fine and characteristic linin-reticulum there is developed a distinct chromatin-spirem as in higher plants, a condition which does not obtain in tetraspore mother-cells (Fig. 18). The spindle reaches maturity before the membrane of the mother-nucleus disappears (Fig. 19). At this stage 
and later no polar radiations were seen, or only a very few. The rod-shaped centrosomes were, however, always present (Figs. 19, 20, 2I). In some cases observed, when the daughter nuclei were provided with membranes, the centrosomes possessed a few faint polar radiations (Fig. 22). The chromosomes are short, bent, slightly U-shaped, and about thirty-two in number. They lie closely crowded together, so that counting is difficult, and the number could not be exactly ascertained.

Regarding the body which is known as a centrosome among the Brown Algae, the old questions of morphological unity and phylogenetic origin still present themselves. It is not my purpose, however, to go into the voluminous literature touching upon these and similar questions, nor to discuss the various and conflicting theories that have been advanced from time to time. I shall content myself with a brief presentation of the facts as I have observed them in Dictyota and as they are known in Fucus and the Sphaceleriaceae.

In the young tetraspore mother-cells of Dictyota, before they have increased noticeably in size, no centrosomes with their characteristic radiations were seen, nor were any observed in vegetative cells showing no sign of karyokinetic activity.

Throughout the two divisions in the tetraspore mothercells the centrosome is unquestionably present at all stages, and in the germinating tetraspore and the first three or four cell-generations of the seedling plant resulting therefrom, the persistence of this body is undeniable. In Fig. 23 is shown a tetraspore which has begun to germinate. The structure of the nucleus itself does not indicate any karyokinetic activity, and we may say that it is in the resting condition, but the very evident centrospheres are in the position of the future poles of the spindle. The centrosomes are also rod-shaped, and, as elsewhere, can be seen with the greatest clearness. A daughter nucleus resulting from the first division in the spore is shown in Fig. 24. The same may be said of the next two or three successive generations 
of cells. Further than this no observations were made in the seedling plant. A nucleus from an enlarging epidermal cell, previous to the division which will cut off the stalk-cell of the tetrasporangium, is seen in Fig. 25. Here, too, the centrospheres are well developed at the beginning of the prophase.

In the light of what we now know in Fucus, certain Sphaceleriaceae and Dictyota, it seems evident that the body which in these plants has been called a centrosome, is one that persists from one cell-generation to another in vegetative and certain reproductive cells; it is capable of division, and is the centre of radiations that give rise to the karyokinetic spindle with its mantle and polar fibres. These facts seem to argue that the centrosome is a morphological unit of the cell, and by the cytologist who is eager to support this theory they may be deemed sufficient, but are they conclusive? While I admit that this evidence is the strongest that has, as yet, been advanced, nevertheless I am not convinced that it is conclusive proof, for there are other questions suggested here and in the higher plants which require further elucidation. We may appropriately inquire what the relation existing between the centrosome and its surrounding radiations is. Are the radiations outgrowths of the centrosome as a primary morphological unit or organ? Or are they constructed out of a differentiated part of the cytoplasm, say the kinoplasm, by the centrosome as a centre of activity? Or, finally, is the centrosome only a denser mass of kinoplasm formed by the meeting of the polar radiations and spindle-fibres?

The answer to these questions will necessarily influence our conception of the centrosome and also the significance of what we term kinoplasm.

When certain Algae and Fungi are considered alone, nothing is more plausible than that the radiations grow out of the centrosome as a primary source. In the higher plants, however, where there are no centrosomes, this argument will not stand, for there is no good reason to believe that the spindle-fibres in the Lily are not homologous with those in the Brown Algae or in Fungi. If kinoplasmic fibres which 
go to make up the spindle are controlled in certain lower plants by the centrosomes as centres of force, how is it that the same fibres in higher plants construct a karyokinetic figure without centrosomes or individualized centres of force?

Harper ('99, p. 510), in the latest of his most excellent papers upon certain Fungi, is inclined to the view that the central body in the Ascomycetes is due to the meeting of spindle and ray-fibres. Speaking of the spindle in the ascus of Lachnea scutellata, he says: "The ends of all these spindles in the equatorial plate stage are decidedly broad and blunt, and the central body in which they end is flat and disk-shaped, as in Peziza Stevensoniana and Ascobolus. It stains more densely than the rays or spindle-fibres, but there is no indication that it is more than a denser mass of kinoplasm formed by the meeting of the spindle and rayfibres.' ·

Now there may be a question whether the 'central body' in the Ascomycetes is homologous with the centrosome in Dictyota or the other Phaeophyceae, but I am inclined to think that the behaviour of these bodies leaves little doubt as to their homology.

In Dictyota the centrosome is certainly not formed by the meeting of polar radiations and spindle-fibres, for it exists and divides when only one set of these fibres is present, and perhaps also when both sets are absent, as, for example, in the early prophase or resting stage of the primary nucleus of the tetraspore mother-cell.

With all the facts taken into consideration it seems to me that it is the kinoplasm which should hold the rank of morphological unit, and the centrosome be considered as an individualized part of the same, existing in that form in some organisms and not in others, and being the expression of certain activities of the living substance, which are still largely beyond the power of the investigator to comprehend and explain. It is the opinion of the writer that this view is more in harmony with all the facts now known in both plants and animals. It is also clear to me, moreover, that neither 
this nor any other doctrine hitherto proposed is without objection. Any theory dealing with what we call a centrosome, wherever that may be found, must deal also with the kinoplasmic radiations and spindle-fibres associated with it, and any theory assuming the morphological unity of the centrosome similar to that of the nucleus, without at the same time taking into account the kinoplasmic fibres of the karyokinetic figure in higher plants, is inadequate.

\section{The Formation of the Cell-Plate.}

Within the last few years our knowledge of cell-formation has been greatly extended, and in some respects revolutionized, especially as regards the so-called processes of free cell-formation. The method by which the cell-plate or plasma-membranes are laid down in higher plants no longer finds such universal application as was formerly attributed to it.

The investigation of Strasburger ('97) and Swingle ('97) on the Phaeophyceae, and those of Harper ('97, '99) on the Ascomycetes and Phycomycetes, have opened up a new field of research.

The type of cell-plate formation in the Brown Algae differs from those described by Harper in the Fungi as well as from that in the higher plants. It seems possible, however, that in all of these apparently diverse types the plasma-membranes are laid down through the agency of the kinoplasm, although this may not be demonstrable as sharply differentiated radiations or as connecting fibres.

In Fucus, according to Strasburger ('97, p. 358), when the eight nuclei are distributed in the cytoplasm of the oögonium and the formation of the cell-plate begins, the centrosomes are no longer to be recognized and the kinoplasm cannot be distinguished from trophoplasm. The cell-plate arises in the trophoplasm, whose alveolar walls so arrange themselves as to form a continuous plasma-membrane.

'Die Verbindungsfäden zwischen den Tochterkernen werden 
hier ebenso wenig wie in den früher von mir studirten Sphacelariaceen ('92) vermehrt und bei der Bildung der Scheidewände verwerthet. Vielmehr entstehen die Scheidewände in dem wabigen Trophoplasma, dessen Waben sich entsprechend anordnen, um aus ihren Wänden fortlaufende Plasmaschichten herzustellen. Dass die sich bildenden Hautschichten, welche die Eier von einander trennen sollen, aus Trophoplasma hervorgehen, wird durch diese ihre Entstehung in den Wabenwänden des Trophoplasma noch nicht erwiesen. Ja, manche Erscheinung sprach hier dafür, dass dem nicht so sei. Ich beobachtete nämlich wiederholt in den Plasmalamellen, welche den neuen Hautschichten den Ursprung geben sollten, kleine, dicht aneinander schliessende Körner, die bei günstiger Anwendung des Orange-Verfahrens violett gefärbt erschienen (1.c., Fig. 22, Taf. XVII). Dort, wo die Hautschicht bereits erzeugt und eine Spaltung derselben erfolgt war, zeigten sich diese einfachen Körnchenplatten in zwei Platten entsprechend kleinerer Körnchen getrennt' (1. c., Fig. 22, Taf. XVII).

From the foregoing quotation it is evident that Strasburger attributes the actual formation of the plasma-membrane (Hautschicht), which constitutes the cell-plate, to the union of closely arranged kinoplasmic granules that afterwards split to give rise to the plasma-membranes forming respectively the contiguous surfaces of each daughter cell.

These kinoplasmic granules are compared to the thickenings of the connecting fibres, which takes place in cell-plate formation in higher plants, and in this respect the influence of his older doctrine is noticeable.

In Stypocaulon Swingle ('97) finds that the first indication of a cell-plate is seen in a group of alveolae which show a tendency to arrange themselves across the cell in a transverse plane (1. c., Figs. 3, 6, Taf. XV). As soon as this orientation of alveolae becomes more marked, the transverse alveolar lamellae form a more continuous plane, which in section appears as a very fine line.

During these changes neither an increase in the number of 
connecting fibres between the nuclei nor any perceptible change whatever in the arrangement of the kinoplasm was to be seen. Only a few fibres or lines of force, indicated by the arrangement of the alveolae of the frothy plasma, extend from the nucleus of the apical cell to the seat of the cell-plate formation, and still fewer from the lower nucleus to the same place (1. c., Fig. 5, XV). It is certain, he further remarks, that if these be real fibres, they must be extremely delicate and not numerous enough to lead one for a moment to suppose that the cell-plate is laid down by any such process as in the Metaphytes. And although the entire phenomenon is a process which does not depend immediately upon the activity of the kinoplasm, yet it is not impossible that it takes place under the control of the nucleus exerted through the kinoplasmic fibres which connected the latter with the former cell-plate.

The development of the cell-plate in Dictyota resembles that in Stypocaulon. There is absolutely no visible trace of kinoplasmic connecting fibres between the nuclei, and in the region of the cell-plate the cytoplasm seems undifferentiated.

The plasma-membranes or cell-plates which will separate the four spores are laid down nearly simultaneously. In the regions where they are to appear, the cytoplasm, as elsewhere, except near the nuclei, reveals the same visible structure of alveolae, or perhaps a mixture of alveolar and thread-like network. Rather large and very small meshes are intermingled. The smaller-meshed structure is apparently more granular than that with larger meshes.

The first visible trace of a cell-plate is manifested by the transverse walls of the alveolae becoming perceptibly thicker and arranging themselves in such a way as to appear as an uneven or somewhat zigzag line in section (Fig. I6). In this cell-plate rudiment or Anlage, the walls of both large and small meshes take part. At first certain of the alveolar walls are thinner than others, so that the cell-plate seems interrupted at those places, but eventually and gradually it attains a uniform thickness. Very soon the cell-plate or 
plasma-membrane is a uniform plane which in section appears as a smooth line.

The cell-plate is not always laid down everywhere simultaneously, but sometimes it appears at first more marked at the periphery. This seems to depend upon the position of the nuclei.

It must be admitted that this process of cell-plate formation is very different from what takes place among the higher plants, where we have a plasma-membrane formed by the connecting fibres. If there be kinoplasm present, it does not exist in the form of visible fibres, such as connecting fibres, but what is really seen, seems, in part at least, to be a direct transformation of the walls of the alveolae into the cell-plate.

All of this does not prove, however, that kinoplasm is not present, or that it is not instrumental in forming the plasmamembrane, which, there are strong reasons to believe, is composed of this substance.

Shortly before the cell-plate is marked as a continuous and somewhat irregular line, as described, the region in which it will appear is sometimes to be distinguished by the presence of fewer chloroplasts and somewhat finer meshes of the cytoplasm. The region stains more nearly like the kinoplasm near the nuclei, and when the plasma-membranes are formed, they also retain the gentian violet with greater avidity than the cytoplasm in general, especially if the fixing fluid were stronger in osmic acid. I have found it to be almost invariably true, both in pollen mother-cells and vegetative tissue of the higher plants, as well as in Dictyota, that in material fixed in the solutions stronger in osmic acid, e.g. solution $A$ above, the spindle-fibres, or kinoplasm, stained a much deeper blue than when solutions weaker in osmic acid were used; and it may be added that the secret in the use of the chromosmic-acetic solution is to determine the proper amount of osmic acid necessary to make possible the best differential staining. The conclusion, therefore, is not unwarranted that in Dictyota the cell-plates are formed by means of kinoplasm. 
This point of view does not assume that everything which remains blue after careful differential staining with the triple stain used is kinoplasm, nor is it claimed that the colour of any part of the plasma, resulting from a certain staining method, indicates the chemical nature of the part so stained. The colour may or may not do so; decisive proof is still wanting.

In vegetative cells the formation of the cell-plates is likewise interesting. The connecting fibres between the daughter nuclei disappear as such (Fig. 22), and the plasma-membrane seems to be laid down as in the delimination of the tetraspores. It was not possible to follow the process in as great detail as in the tetrasporangium, but in the case observed the cellplate began at the periphery of the cell and proceeded toward the centre (Fig. 22). The process is not a cleavage, as described by Harper for Zygomycetes, nor is it similar to the Spirogyra or Cladophora type, but is the same as described above. Fig. 22 is not magnified sufficiently to show the finer details clearly.

We have now to consider more fully the nature of the cell-plate, what its finer structure is, and whether it is formed double or as a single membrane, which afterwards splits to furnish the daughter cells with their respective portions of plasma-membrane.

In the pollen mother-cells of Lilium (1. c., '97) I showed that the cell-plate was formed through the direct agency of the connecting fibres, but the precise manner in which its substance was deposited was left an open question. 'Es unterliegt (1. c., p. I92), wie es mir scheint, keinem $Z_{\text {weifel, }}$ dass die Verbindungsfäden in directer Beziehung zu der Zellplattenbildung stehen, doch in welcher Weise, bleibe dahingestellt.' There the cell-plate is, at first, so far as can be seen, a single homogeneous disk separating the daughter protoplasts. Later, it appears double, when the contiguous surfaces of the two cells are provided each with a plasmamembrane (Hautschicht), between which a cell-wall is formed. Whether the cell-plate in either Lilium or Dictyota is laid 
down as a single membrane, which afterwards splits, or whether two membranes are formed from the beginning, is difficult to decide. I am inclined to think that it is laid down as a double plasma-membrane, since evidence of the process of actual splitting was not seen, and immediately the cell-plate is formed, plasmolysis shows that each protoplast has its own plasma-membrane.

Concerning the form in which the cell-plate substance is deposited, there may be much diversity of opinion. In the higher plants, we may contend with Strasburger ('98, p. 514), that the plasma-membrane is formed by the lateral fusion of the thickened connecting fibres, when it would consist of many very small kinoplasmic rods; or we may assume that the cell-plate substance is deposited as a homogeneous fluid. Both in the higher plants and in Dictyota there is much that supports the second of these assumptions.

That the cell-plate in the higher plants is formed by the lateral union or fusion of the thickened connecting fibres may be seriously questioned, for in some cases these fibres do not thicken very appreciably in the equatorial region, nor do they lie sufficiently close to one another to enable the slightly thickened middle parts to meet and fuse laterally. I refer, for example, to the formation of the egg-cell in the embryo-sac of Lilium Martagon (Mottier, '98, Taf. III, Fig. 2I). There the connecting fibres are only very slightly thickened in the region of the cell-plate, and they are too far apart to lead one to believe that the plasma-membrane is the result of the lateral fusion of the slight equatorial thickenings of these fibres. In this and in similar cases among higher plants, the conclusion seems justifiable that the cell-plate is formed by homogeneous plasma which is conveyed to the cell-plate region and deposited there by the connecting fibres.

In Dictyota there are no connecting fibres, neither does the cell-plate consist, at first, of a row of granules which - split later to form the two plasma-membranes as described by Strasburger ('97, p. 359) for Fucus. The cell-plate does 
contain very small granules similar to those observed everywhere in the framework of the cytoplasm, but in Dictyota they are not arranged in a definite plane to form a cellplate. Their part in the process is secondary.

If, therefore, we accept the doctrine of a morphological differentiation of the cytoplasm, we have in Dictyota a cellplate formed of kinoplasm, which neither exists in the form of connecting fibres, nor is its substance conveyed to the cellplate region by such fibres. The possibility is not excluded, however, that the kinoplasm may exist in the form of fibrillae as claimed by Strasburger, and these fibrillae may constitute a fine network, distributed among the alveolae or applied to the walls or lamellae of the latter, when its fibrillar nature would be obscured ; or it may exist in the form of a homogeneous fluid, evenly distributed over the firmer framework of the remaining cytoplasm, whether the latter be a threadwork or alveolar in structure.

It is the opinion of the writer, therefore, that, in such cases as Dictyota and Stypocaulon, the cell-plate or plasmamembrane is laid down by kinoplasm which is not differentiated in the form of conspicuous fibres, but that it exists in one of the forms just mentioned. There is reason to believe, also, that in many plants where a visible differentiation of the cytoplasm is not manifest, plasma-membranes are formed in a similar manner.

\section{The Chromosomes.}

As regards the question of chromosome-reduction, I am able to contribute comparatively little that is definite or conclusive.

The researches of Farmer and Williams and Strasburger have shown that in Fucus the reduced number of chromosomes appears in the oögonium, while in vegetative cells of the thallus twice that number is present. Strasburger ('97) finds that in the first nuclear division in the oögonium the reduced number appears, fourteen to sixteen having been 
counted, and this number persists throughout the two succeeding mitoses. In vegetative cells the number is not far from thirty.

In Dictyota the first nuclear division in the tetraspore mother-cell, as already stated, reveals the reduced number. Here sixteen chromosomes were counted. In vegetative cells the smaller size and the crowding together of the chromosomes make counting more difficult and less accurate, but in several instances the number was found to be not less than thirty, and one may reasonably suppose that thirty-two is the normal number.

The two nuclear divisions in the tetraspore mother-cells are strikingly similar to those in spore mother-cells of higher plants. The tetraspore, being borne, as it seems, by the gametophyte, may not be homologous with the spores of higher plants, and consequently to speak of the nuclear divisions in the former as homologous with those in the latter might lead to confusion. The fact that these types of karyokinesis occur so universally in reproductive cells of widely divergent groups of organisms in both the vegetable and animal kingdoms forces upon one the conclusion that they are of the utmost theoretical importance.

If the reduction in the number of chromosomes should prove to be of as far reaching significance as is generally supposed, Dictyota offers, beyond any doubt, a most interesting field for speculation and further research.

Whether in the nuclei of the seedling plants arising from tetraspores the reduced number of chromosomes persists, and whether in the egg-cell the reduced number obtains, are problems which further research must solve. Unfortunately I was unable to obtain the proper stages of karyokinesis to ascertain the number of chromosomes in the cells of the seedling plants in question, nor was the division by which the stalk-cell of the oögonium was cut off, observed so that the number in the egg might be determined. In this respect it is of prime importance that the sequence of generations, arising from the tetraspores and from the fecundated egg, be ascertained with accuracy, and that the number 
of chromosomes be known also in the vegetative cells of these generations.

For the solution of these problems a thorough and prolonged study at the sea-shore is necessary.

\section{Summary.}

When we consider the facts presented in the foregoing paragraphs concerning the development of the karyokinetic figure, it will be seen that in Dictyota the nuclear spindle originates in two systems of kinoplasmic radiations or asters that lie close to the nuclear membrane and some distance from each other, generally on opposite sides of the nucleus. The radiations of each system are centered upon a very distinct rod-shaped body, the centrosome. For the sake of convenience I have spoken of the centrosome together with its radiations as a centrosphere. The centrosome is present during the two nuclear divisions which take place in the tetraspore mother-cell ; it is also found in the germinating tetraspores, and its persistence has been observed in the first three or four cell-generations of the resulting seedling plant. In all vegetative cells of the thallus bearing tetraspores, the centrosome is readily recognized during karyokinetic activity. In the beginning of mitosis it divides longitudinally, and the daughter centrosomes with their radiations, or we may say the daughter centrospheres, move apart along the nuclear membrane to positions occupied by the poles of the future spindle. During the process of karyokinesis, the centrosomes may undergo a change in size, appearing smaller in the equatorial plate stage.

The fact of the persistence of the centrosome from one cell-generation to another, and of its multiplication by division, is certainly strong evidence in favour of its morphological unity as an organ of the cell. In the light of what is known in the higher plants, and owing to our limited knowledge of karyokinetic activity in the lower plants, I do not think we 
are justified in attributing to the centrosome the morphological rank of an organ, such as the nucleus. It is, it seems to me, more in harmony with all facts pertaining to the subject to regard the centrosome as a special individualized part of the kinoplasm, existing in that form as the expression of certain activities which are as yet not well understood.

In comparing the development of the spindle in Dictyota with that of Stypocaulon, a close resemblance of the two is at once apparent. From each pole or centrosome kinoplasmic fibres enter the nuclear cavity. The membrane of the nucleus is unbroken at first, but later it gradually disappears at the poles. The remaining part of the membrane persists until a very late stage, sometimes after the spindle is mature.

The entering cones of spindle-fibres present less regular and even bases than those in Stypocaulon, a fact due to the more rapid growth of certain fibres. These cones meet in the equatorial region to form that part of the spindle between the poles. By this process the chromosomes are brought into the equatorial plate.

During the prophase of both divisions in the tetraspore mother-cell the behaviour of the chromatin differs strikingly from that in the higher plants. There is not developed here a regular and continuous chromatin-spirem which segments into the chromosomes, but these arise as isolated masses, often differing much in size. It gives the impression that the quantity of chromatin is not sufficient to form a continuous spirem. In the vegetative cells, on the contrary, there is developed a typical spirem as in the higher plants.

The reduced number of chromosomes, namely sixteen, appears in the first nuclear division in the tetraspore mothercell. This division is quite analogous to the heterotypic division in spore mother-cells of most cormophytes. In the vegetative cells of the thallus bearing tetraspores the number is estimated at thirty-two.

The behaviour of the nucleolus, during both the development of the nuclear figure and the construction of the daughter 
nuclei, indicates that this body represents a substance which is utilized by the chromatin and not by the spindle-fibres.

The development of the cell-plate or plasma-membrane in Dictyota belongs to the same type as that of Stypocaulon. No differentiated connecting fibres of any sort can be recognized. It seems that the apparently undifferentiated framework of the cytoplasm, consisting of large and small meshes in the immediate region of the cell-plate, is converted into a plasma-membrane. The behaviour of the cell-plate toward certain stains, and the character and behaviour of the cytoplasm in that region, immediately preceding the appearance of the plasma-membrane, as described in a foregoing paragraph, strongly suggest that the latter is not an actual transformation of the alveolar walls, but that the substance of the cell-plate is deposited by kinoplasm, which is present in the framework of the cytoplasm. The form in which this kinoplasm occurs here is difficult to determine. It does not matter, however, for our explanation, whether it takes on the form of a fibrous network or of alveolae.

As has already been mentioned, this type of cell-plate formation is different from that in the higher plants where connecting fibres are present, yet it bears a closer resemblance to the latter, perhaps, than to any of the several other methods known in the vegetable kingdom. It is not a cleavage as described by Harper ('99) for the Phycomycetes, nor is it in any way similar to the process of division by constriction that exists in either Cladophora or Spirogyra. Further investigation, especially in thallophytes and archegoniates, will probably bring to light transitions between the several distinct types of cell-formation that are now known among Algae, Fungi, and higher plants. 


\section{LITERATURE.}

Farmer, J. B., and Wrlliams, J. L., '96: On Fertilization and the Segmentation of the Spore in Fucus. Ann. of Bot., x, I896, p. 48I.

'98: Contributions to our Knowledge of the Fucaceae: Their LifeHistory and Cytology. Phil. Trans. of the Royal Society, London. Series B. 190,1898 .

HARPER, R. A., '97 : Kerntheilung und freie Zellbildung im Ascus. Jahrb. fo wiss. Bot., $\mathrm{xxx}, \mathrm{I} 897$.

'99: Cell-Division in Sporangia and Asci. Ann. of Bot., xiii, 1899.

Mottier, D. M., '98: Das Centrosom bei Dictyota. Ber. d. D. Bot. Gesellsch., xvi, I 898 .

'97: Beiträge zur Kenntniss der Kerntheilung in den Pollenmutterzellen einiger Dikotylen und Monokotylen. Jahr. f. wiss. Bot., xxx, I897.

'98: Ueber das Verhalten der Kerne bei der Entwickelung des Embryosacks und die Vorgänge bei der Befruchtung. Jahrb. f. wiss. Bot., xxxi, 1898 .

Strasburger, E., '97 : Kerntheilung und Befruchtung bei Fucus. Jahrb. f. wiss. Bot., $\mathrm{xxx}, \mathrm{I} 897$.

'98: Die pflanzlichen Zellhäute. Jahrb. f. wiss. Bot., xxxi, 1898.

'92 : Schwärmsporen, Gameten, \&c. Histol. Beitr., Heft iv, I $89^{2}$, p. 56 .

Swingle, W. T., '97 : Zur Kenntniss der Kern- und Zelltheilung bei den Sphacelariaceen. Jahrb. f. wiss. Bot., xxx, I897.

Williams, J. L., '97 : The Antherozoids of Dictyota and Taonia. Ann. of Bot. xi, 1897 .

\section{EXPLANATION OF FIGURES IN PLATE XI.}

Illustrating Professor Mottier's Paper on Nuclear and Cell Division in Dictyota.

All figures were drawn from sections with the aid of the Abbe camera lucida and with the Zeiss apochromatic homogeneous immersion $2.0 \mathrm{~mm}$., Apert. 1.40. Figs. I-1 5,24 and 25 with compensating ocular 6 , image distance $30 \mathrm{~cm}$. (i.e. distance from camera mirror to drawing paper). ( $x$ 1200). Figs. 9, I6-2I, with compensating ocular I2, image distance $20 \mathrm{~cm}$. ( $x$ I800). Figs. 22 and 23, ocular 4 , image distance $20 \mathrm{~cm}$. ( $\times 625)$.

Figs. I-8 pertain to the first nuclear division in the tetraspore mother-cell. 
Fig. I. Nucleus in prophase with centrospheres on opposite sides; at the upper end the centrosome is seen from the side, that at the lower is seen from the end.

Fig. 2. A somewhat later stage. Nucleus with surrounding cytoplasm and chloroplasts. The centrospheres are large, with dense radiations; the chromatin has collected in larger irregular masses; the nucleolus is very large and vacuolated. To the left within the nucleus are numerous fine granules.

Fig. 3. The spindle-fibres have begun to penetrate the membrane and enter the nuclear cavity at the poles; chromatin masses large; nucleolus more finely vacuolate. At the poles the nuclear membrane is infolded, dne probably to a slight shrinkage.

Fig. 4. The cones of penetrating fibres are much larger; a few of the fibres have met at the equator to form the continuous spindle-fibres extending from pole to pole. The chromosomes are collecting in the region of the nuclear plate. The nucleolus has almost or quite disappeared, while numerous smaller but densely staining granules are present; a fine threadwork, presumably linin, is also to be seen.

Fig. 5. A nearly mature spindle. The centrosomes are smaller and partly obscured by the numerous fine radiations and spindle-fibres centred upon them; at the sides the nuclear membrane is still preserved.

Fig. 6. A mature spindle, showing chromosomes arranged regularly in equatorial plate, and the following orientation of spindle-fibres: those extending uninterruptedly from pole to pole; the bundles of contracting fibres attached to the chromosomes and extending to the centrosomes; the mantle-fibres, or those diverging toward the nuclear membrane in the direction of the equator and the polar radiations. As in the two preceding figures traces of the nuclear membrane are visible at the sides.

Fig. 7. One end of a karyokinetic figure in the anaphase. The chromatin masses never approach nearer to the centrosome.

Fig. 8. Two daughter nuclei with surrounding cytoplasm; the nuclear membranes have just been laid down; the chromatin is in the form of a lumpy mass, near which is a very evident nucleolus, and a linin network with granules is also present. The connecting fibres have nearly disappeared, while the polar radiations have become more pronounced and the centrosomes larger in size.

Figs. 9-15. Division of the daughter nucleus.

Fig. 9. Daughter nucleus at a little later stage than Fig. 8, more highly magnified. The centrosome has just divided, the segments having separated at one end, but still almost touching at the other, so as to form a shallow V-shaped figure. The attachment of the fibres to the daughter segments suggests that the former exert a pulling force upon the latter.

Fig. 10. A later stage in which the centrospheres have moved apart a short distance. The nucleus reveals the structure of the resting condition.

Fig. II. The beginning of the formation of the spindle; only one pole is shown, the other lying in the next section. As in the corresponding stage of the preceding division, the fibres of the spindle-cones are of unequal length, and the nuclear membrane is as yet unbroken. The nucleolus is vacuolate; the chromatin is represented by small but densely staining masses, and the linin is in the form of a small-meshed and finely granular threadwork.

Fig. I 2. The centrospheres do not lie upon exactly opposite sides of the nucleus. (This figure lay somewhat obliquely to the plane of the section, so that a con- 
siderable change of focus was necessary in drawing to include both centrospheres, and for this reason the centrosomes are a little nearer in the drawing than is really the case.) The spindle-cones, now well developed, have their bases turned toward the masses of chromatin and disorganized nucleolus; the polar radiations are few and indistinct.

Fig. 13. The cones of fibres have formed a curved spindle; the nuclear membrane is still unbroken, except perhaps directly at the centrosomes.

Fig. 14. A mature spindle with the same orientation of fibres; the chromosomes, however, have fused into large masses.

Fig. I5. A later stage, probably metakinesis.

Fig. 16. A portion of a cell-plate (see text for further explanation).

Figs. I 7-22 pertain to nuclei of vegetative cells.

Fig. I7. Nucleus of an epidermal cell not far from the growing point, in the resting stage; the centrosphere is present, but the kinoplasm occurs in smaller quantities than in reproductive cells.

Fig. I8. Nucleus is prophase, showing chromatin spirem and large nucleolus.

Fig. 19. Spindle with chromatin in equatorial plate; centrosomes very distinct, but no polar radiations; the entire nuclear membrane is present.

Fig. 20. Similar to the preceding, but from a larger cell; the nuclear membrane (not drawn) had partly disappeared.

Fig. 2I. Anaphase; the chromosomes are crowded into a mass so that the limits of the individuals are scarcely recognizable; the centrosomes are smaller than at an earlier stage.

Fig. 22. An epidermal cell of the thallus. The daughter nuclei are provided with membranes, and the centrosomes, with fewer radiations, are present; on either side of the region formerly occupied by the connecting fibres cell-plate rudiments are seen. The connecting fibres have been replaced by a network which stains as kinoplasm.

Fig. 23. A germinating tetraspore. The centrospheres are on nearly opposite ends of the nucleus, which is structurally in the resting stage. The framework of the cytoplasm is more or less radially disposed about the nucleus.

Fig. 24. Daughter nucleus, resulting from the first division in the tetraspore after cell-division is complete. The nucleus is in the resting stage, yet the centrosphere shows that the karyokinetic activity of the next mitosis has begun. The persistence of the centrosome here is unquestionable.

Fig. 25. A nucleus taken from an enlarging epidermal cell, which gave an indication of development into a tetrasporangium. 

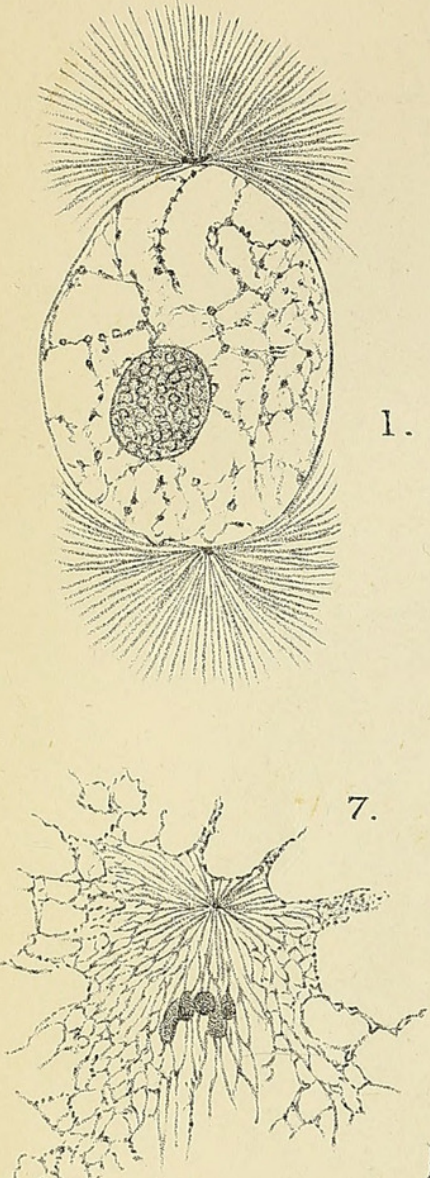

1.

2.

(1) 0 रिखि

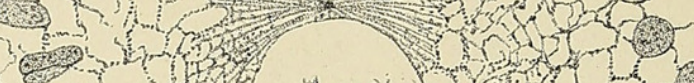

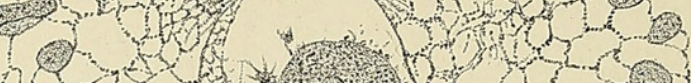

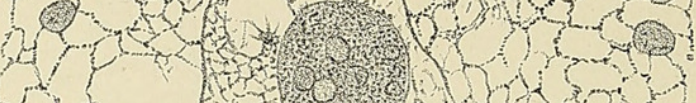

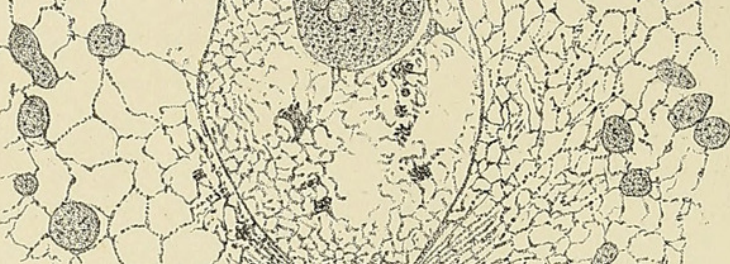

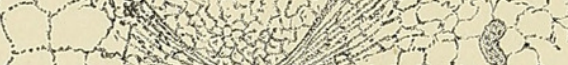
a t a ? ex 3 (a) (2)

\section{(2)}

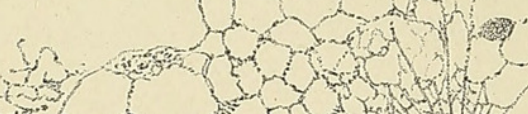

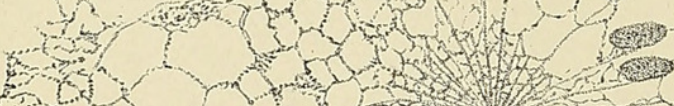

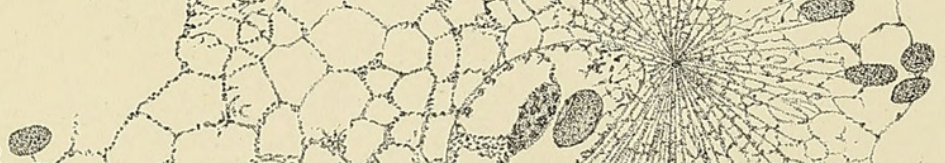

8. 1 a

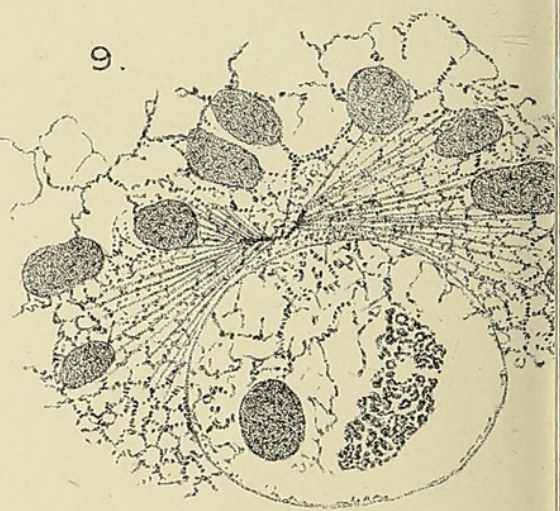

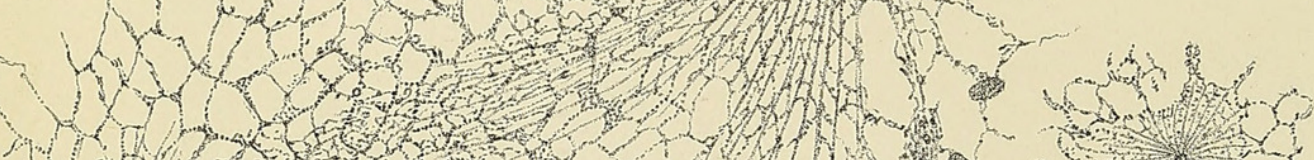

(3) 30 (3)

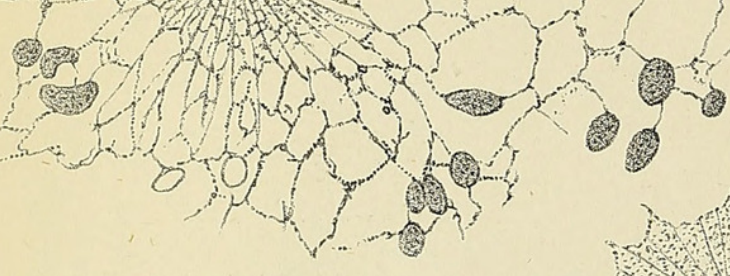

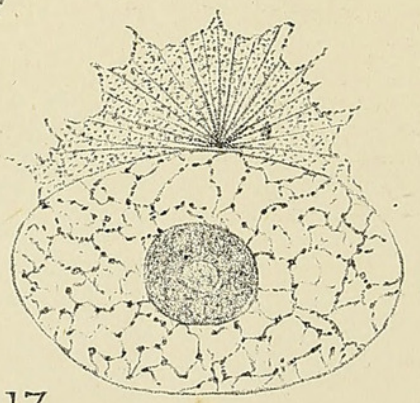

14.

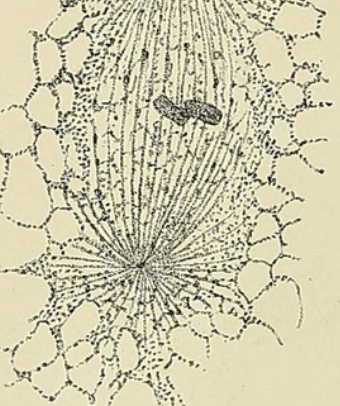

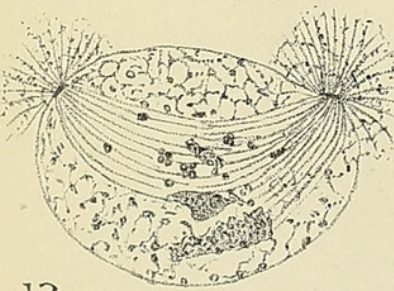

13.

17

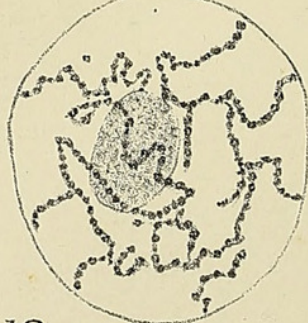

18
3.
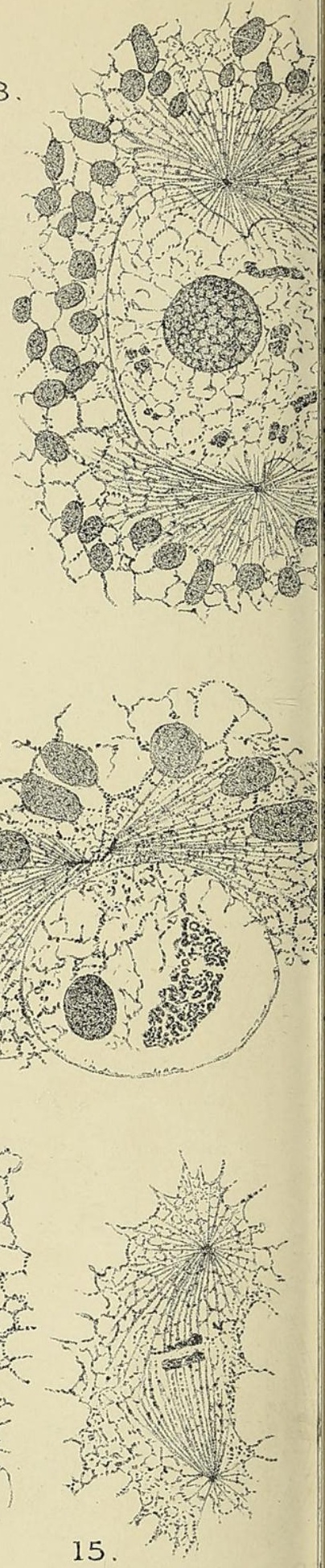

15

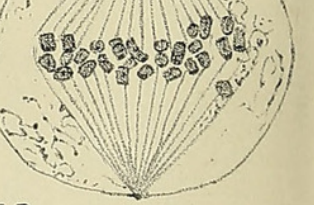

D. M. Mottier del.

MOTTIER. - ON NUCLEAR AND CELL DIVISION IN DICTYOTA. 
Vol.XIV, PI.XI.
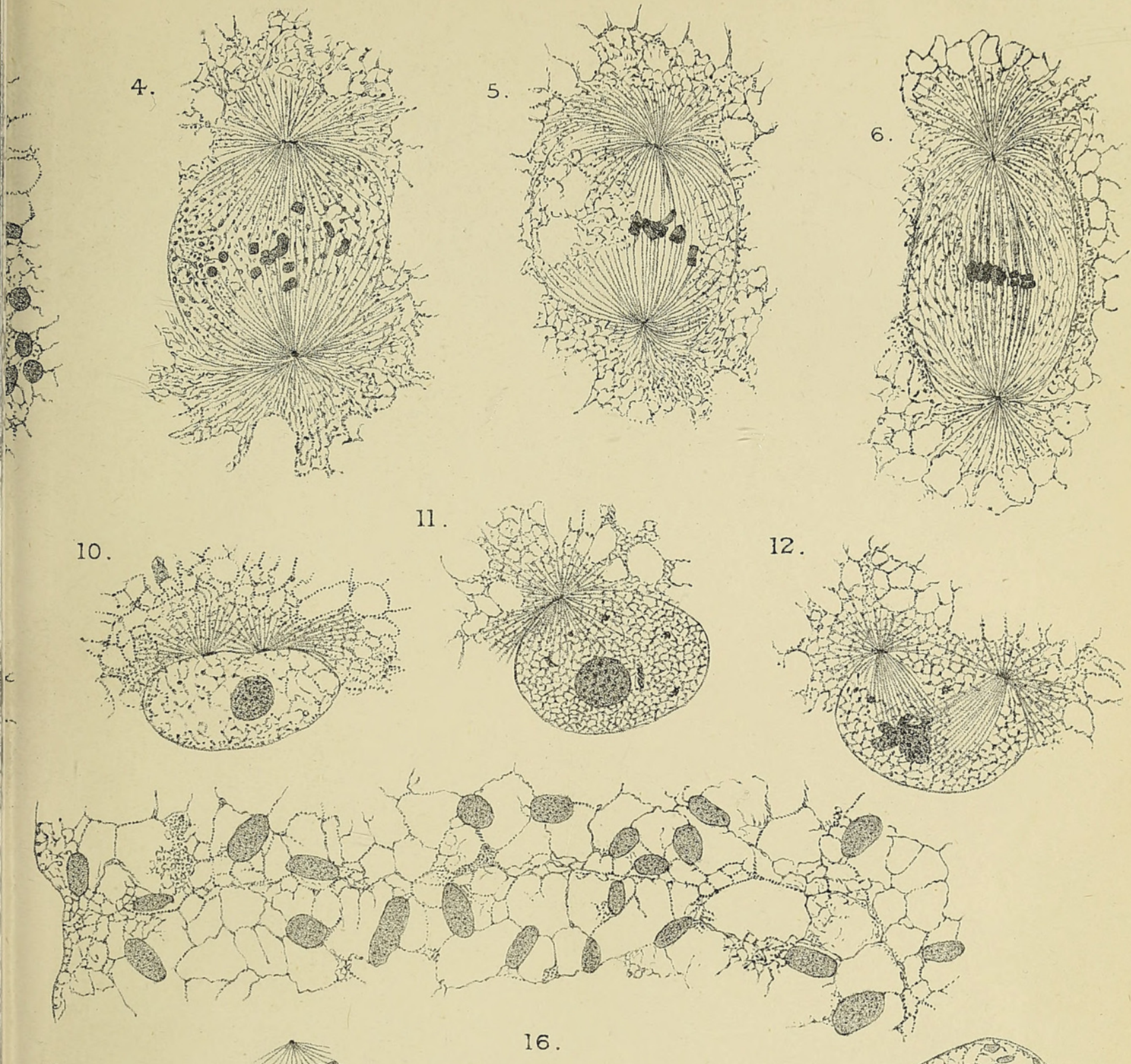

0 .

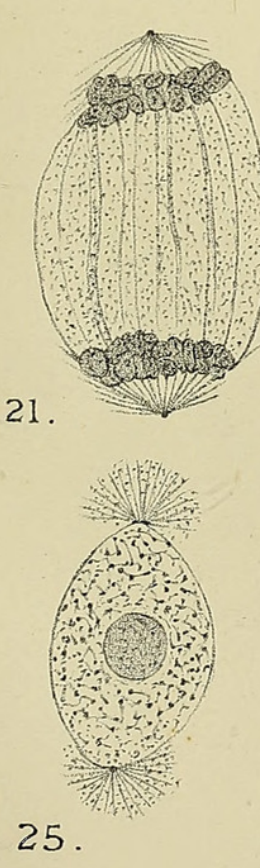

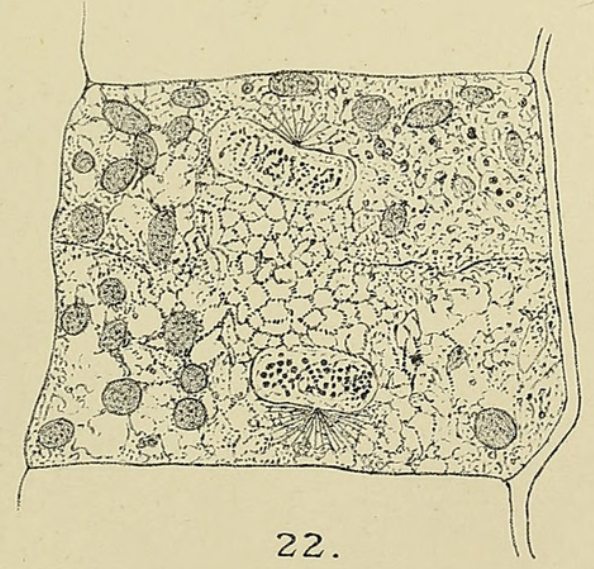

22.

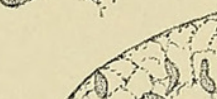

on ol - In do b o and

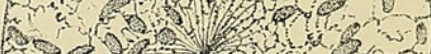

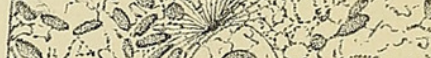
1.50. 0 1 (2) 00

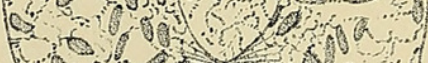
$\left(0-0^{2}-10\right.$ (100 40090

23. $\underbrace{\left(-y^{\prime}\right.}_{(-2)}$ 


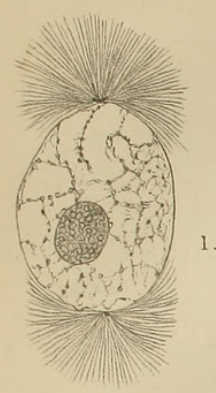

(i)

पit a re

3. a

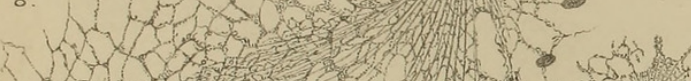

747 .

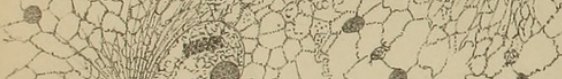
Trom

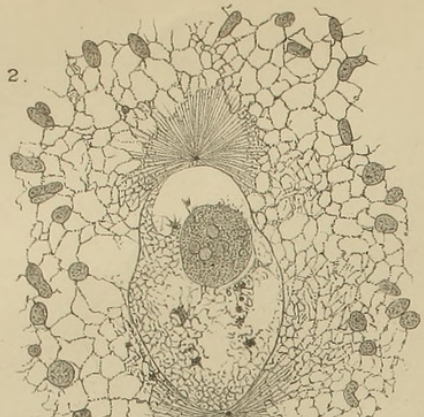

$$
\text { aryan }
$$

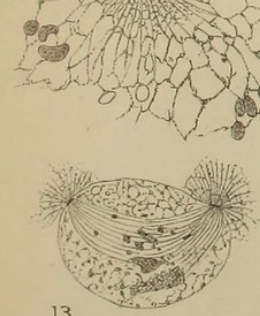

D. M. Mottier del.

MOTTIER. - ON NUCLEAR AND CELL DIVISION IN DICTYOTA.

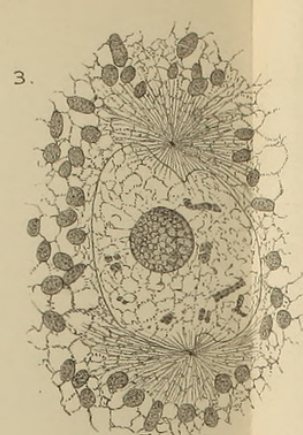

4. 3fents

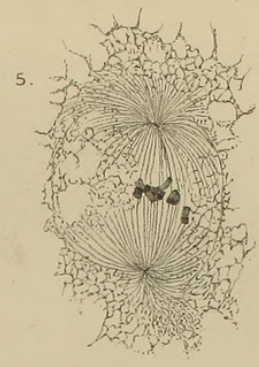

Vol.XIV, PL.XI.
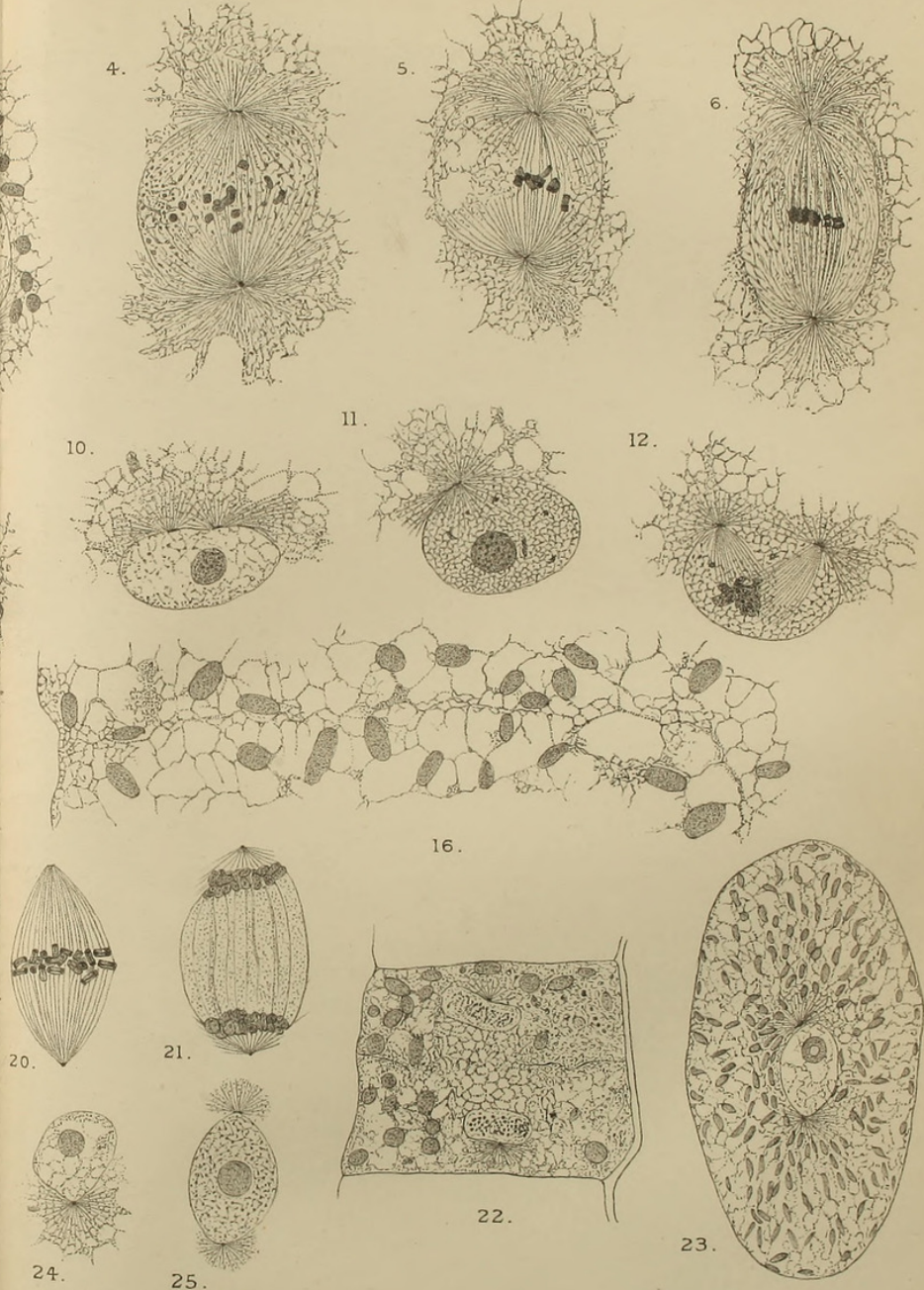

University Press, Oxford. 


\section{$2 \mathrm{BHL}$ Biodiversity Heritage Library}

Mottier, David M . 1900. "Nuclear and cell division in Dictyota dichotoma." Annals of botany 14, 163-192.

https://doi.org/10.1093/oxfordjournals.aob.a088773.

View This Item Online: https://www.biodiversitylibrary.org/item/238259

DOI: https://doi.org/10.1093/oxfordjournals.aob.a088773

Permalink: https://www.biodiversitylibrary.org/partpdf/318580

\section{Holding Institution}

Smithsonian Libraries

\section{Sponsored by}

Biodiversity Heritage Library

\section{Copyright \& Reuse}

Copyright Status: Not in copyright. The BHL knows of no copyright restrictions on this item.

This document was created from content at the Biodiversity Heritage Library, the world's largest open access digital library for biodiversity literature and archives. Visit BHL at https://www.biodiversitylibrary.org. 